Review Article

\title{
Tissue Engineering Approaches for Enamel, Dentin, and Pulp Regeneration: An Update
}

\author{
Geraldine M. Ahmed $\mathbb{D}^{1,2}$ Eman A. Abouauf, ${ }^{1,3}$ Nermeen AbuBakr ${ }^{1 D},{ }^{1,4}$ Christof E. Dörfer, ${ }^{5}$ \\ and Karim Fawzy El-Sayed ${ }^{1,5,6}$ \\ ${ }^{1}$ Stem Cell and Tissue Engineering Research Group, Faculty of Dentistry, Cairo University, Cairo, Egypt \\ ${ }^{2}$ Department of Endodontics, Faculty of Dentistry, Cairo University, Cairo, Egypt \\ ${ }^{3}$ Department of Conservative Dentistry, Faculty of Dentistry, Cairo University, Cairo, Egypt \\ ${ }^{4}$ Oral Biology Department, Faculty of Dentistry, Cairo University, Cairo, Egypt \\ ${ }^{5}$ Clinic for Conservative Dentistry and Periodontology, School of Dental Medicine, Christian Albrechts University, Kiel, Germany \\ ${ }^{6}$ Oral Medicine and Periodontology Department, Faculty of Dentistry, Cairo University, Cairo, Egypt
}

Correspondence should be addressed to Geraldine M. Ahmed; geraldine.ahmed@dentistry.cu.edu.eg

Received 6 December 2019; Accepted 7 January 2020; Published 25 February 2020

Guest Editor: Alireza Moshaverinia

Copyright (C) 2020 Geraldine M. Ahmed et al. This is an open access article distributed under the Creative Commons Attribution License, which permits unrestricted use, distribution, and reproduction in any medium, provided the original work is properly cited.

\begin{abstract}
Stem/progenitor cells are undifferentiated cells characterized by their exclusive ability for self-renewal and multilineage differentiation potential. In recent years, researchers and investigations explored the prospect of employing stem/progenitor cell therapy in regenerative medicine, especially stem/progenitor cells originating from the oral tissues. In this context, the regeneration of the lost dental tissues including enamel, dentin, and the dental pulp are pivotal targets for stem/progenitor cell therapy. The present review elaborates on the different sources of stem/progenitor cells and their potential clinical applications to regenerate enamel, dentin, and the dental pulpal tissues.
\end{abstract}

\section{Introduction}

Dental caries is globally considered among the most prevalent bacterially induced diseases, resulting in enamel and dentin destruction. If untreated, the destruction will mostly lead to irreversible pulpal tissue damage [1]. Currently, the classical line of treatment involves the removal of the affected dental tissues and their subsequent replacement with artificial filling materials, with divergent physi$\mathrm{cal}$ and functional properties [1]. Due to various negative consequences of the restorative techniques and inherent deficiencies of the restoration materials, the ideal solutions to replace defective dental structures could be by biologically restoring/regenerating the lost dental tissues. The development of such new alternative treatment methods is currently considered as an important goal for the dental therapeutic researches.
Mesenchymal stem/progenitor cells (MSCs) are unspecialized plastic-adherent cells with the ability for selfrenewal and multilineage differentiation [2] into multiple cell lineages [3]. They have been isolated from a variety of dental tissues, including dental pulp stem cells (DPSCs), stem/progenitor cells isolated from the human pulp of exfoliated deciduous teeth (SHED), periodontal ligament stem/progenitor cells (PDLSCs), stem/progenitor cells from apical papilla (SCAP), alveolar bone-proper-derived stem/progenitor cells (AB-MSCs), gingival mesenchymal stem/progenitor cells (GMSCs), and dental follicle stem/progenitor cells (DFSCs) $[4,5]$. The stem/progenitor cells derived from the oral cavity express several mesenchymal markers, including CD29, CD73, CD90, and CD105, as well as embryonic markers such as Sox2, Nanog, and Oct4 [6], but lack the expression of hematopoietic markers, including CD34, CD45, and HLA-DR. Relying on their remarkable 
proliferative ability and differentiation potential, these stem/progenitor cells are believed to be very promising in the development of future therapeutic approaches to regenerate the enamel, dentin, and pulpal tissues [7].

\section{The Tissue Engineering Triad}

Tissue engineering is an interdisciplinary field that applies the principles of engineering and life sciences towards the development of biological substitutes that could restore, maintain, or improve tissue and organ functions [8]. The concept of tissue engineering relies on the employment of a triad of stem/progenitor cells, scaffolds, and growth factors $[8,9]$ to regenerate functional biological tissues. Scaffolds have to be implemented with a suitable choice of cells and signaling molecules to initiate the formation of a new dental tissue that can homogenize with the surrounding tissues [10-12].

Numerous stem cell sources have been identified to play an essential role in tissue regeneration. Stem cells are either embryonic or adult stem cells [13]. Embryonic stem cells are immature, undifferentiated cells derived from the inner cell mass of blastocysts $[14,15]$, with the ability to undergo continuous self-renewal and differentiation. Adult stem/progenitor cells are undifferentiated cells that are capable of differentiating into certain types of tissues [3]. They maintain the integrity of tissues they reside in such as blood, skin, bone, and dental pulp [16].

Scaffolds could be natural polymers (e.g., collagen, chitosan, alginate, and hyaluronic acid) or synthetic materials (e.g., polyglycolic acid, polylactic acid, and polylactic polyglycolic acid) and bioactive ceramics, with each category having its merits as well as limitations in use [17]. Scaffolds could be utilized as a cell support tool, upon which cells are cultured in vitro, prior to their transplantation together with their produced matrix in vivo. Scaffolds can further be employed as growth factor/drug delivery tools, to attract body cells to the scaffold site in vivo for new tissue formation [18]. In this context, scaffolds are essential to structurally support and transport growth factors, DNA, biologically active proteins, and cells as well as provide physical signals important for biological repair/regeneration processes $[19,20]$. Aside from these, the topography, architecture, and composition of scaffolds can interact and affect cell response and subsequent tissue formation [18]. It is important for scaffolds to mimic the natural extracellular matrix of the tissue to be replaced $[21,22]$. Optimum design for dental tissue regeneration should be made to achieve mechanical integrity and functionality and to help in cell adhesion and differentiation.

As a third important factor in the tissue engineering triad, growth factors were suggested to be crucial for the regenerative process. They are normally released from cells and are directly presented to cell surface receptors through their interaction with the neighboring extracellular matrix. Binding of growth factors to particular cell-membranelinked receptors activates various mechanisms and pathways involved in tissue engineering such as cell migration, survival, adhesion, proliferation, growth, and differentiation into the desired cell type [23-27]. Especially, bone morphogenetic protein- (BMP-) 2 was shown to induce the differentiation of dental pulp stem/progenitor cells into odontoblasts [23]. It was also demonstrated that BMP-4 mediates the differentiation of human embryonic stem cells into dental epithelium with the ability for tooth formation [28]. In addition, transforming growth factor- $\beta$ (TGF- $\beta$ ) promotes the differentiation of odontoblast-like cells and stimulates dental pulp stem cell-mediated mineralization [23]. Broadly speaking, these growth factor-mediated cell responses are crucial for growth, wound healing, and angiogenesis in repair/regeneration processes [26].

\section{Enamel Regeneration}

3.1. Enamel Structure and Amelogenesis. Enamel, the hardest tissue in the human body, is a highly organized dental tissue, covering the outer layer of the tooth crown. It possesses unique mechanical and structural properties [29-32], relying on its high hydroxyapatite content, the arrangement of apatite crystals into enamel prisms, and finally, the alignment of these prisms in a picket-fence appearance in a tissue of high physical resilience and great hardness [33-37]. Ameloblasts, the enamel-forming cells, are specialized epithelial cells differentiating from the inner cells of the enamel organ [38]. They exhibit polarization and elongation with a pronounced Golgi apparatus and endoplasmic reticulum to form and secrete enamel proteins and influx phosphate and calcium ions into the forming enamel matrix [39, 40]. Enamel proteins are necessary for enamel formation, with amelogenin, ameloblastin, and enamelin being the three major proteins observed in the developing teeth [41]. Recently, this list was amended by amelotin and odontogenic ameloblastassociated protein (ODAM), which were observed in the junctional epithelium and during the maturation stage of amelogenesis [42-45]. Once the enamel matrix is formed, ameloblasts reabsorb water and degrade enamel proteins during the maturation stage of amelogenesis [39, 40]. Finally, they undergo apoptosis and the mature enamel becomes acellular. As a result, once damaged, unlike other biomineralized hard tissues such as dentin and bone, the enamel cannot regenerate by itself $[37,46]$. Therefore, a reparative healing of destroyed enamel depends mainly, if at all, on acellular remineralization of superficial demineralized defects [47].

To restore enamel defects either due to caries, trauma, or others, artificial materials were manufactured to resemble its hardness [48]. Unfortunately, most of the current materials do not possess the same mechanical, physical, and esthetic properties of the lost tissues [49]. Despite the urgent need for tooth enamel regeneration, enamel tissue engineering is facing many difficulties [50-53], including the complex posttranslational protein modifications required for crystal growth [54] and the recapitulation of the unique movements of ameloblasts during the organization of hydroxyapatite crystals into the enamel prisms [55]. Despite all these trials and findings, to date, there exists no scheme for viable cellbased in vivo enamel tissue engineering [37]. The main challenge remains to produce an artificial enamel that resembles the prismatic and interprismatic patterns of natural enamel, 
has the proper anatomy, and can substitute for lost enamelforming cells [56].

3.2. Cells. As enamel-forming cells are lost following tooth development, alternative cellular sources were needed to bring about a cellular-based regeneration. In this context, nondental epithelium-derived human cells, including gingival epithelial cells [57], induced pluripotent stem cells (iPSCs) [58], and human keratinocyte stem cells (hKSCs) $[59,60]$ were suggested to differentiate into enamel-forming ameloblasts when combined with mouse or human embryonic dental mesenchyme. Still, only a small percentage of these explants in subrenal cultures demonstrated the formation of dental enamel [60]. Embryonic stem/progenitor cells were similarly demonstrated to differentiate into oral ectoderm and dental epithelium, using variable concentrations of BMP-4 [61]. The formed dental epithelium, when mixed with mouse embryonic dental mesenchyme and transplanted into renal capsules for thirty days, subsequently generated teeth-like structures, including dentin and enamel, with an incisor-like appearance [28]. Similarly, human keratinocyte stem cells when combined with embryonic mouse dental mesenchyme, sonic hedgehog ( $\mathrm{SHH})$, and fibroblast growth factor 8- (Fgf8-) soaked agarose beads as reconstructed tooth germs [62] and transplanted into mice renal capsules, demonstrated ameloblastic differentiation with enamel deposition. Mouse induced pluripotent stem cells demonstrated a differentiation into ameloblast-like cells, using epithelial rests of Malassez cell-conditioned medium and gelatin-coated dishes, with high expression of amelogenin, ameloblastin, and keratin 14 [63].

Similarly, the Hertwig epithelial root sheath (HERS) and epithelial rests of Malassez (ERM) cells demonstrate a remarkable ability to produce enamel matrix proteins [64]. HERS cells entrapped in cementum produced amelogenin, ameloblastin, amelotin, and ODAM [45]. It was found that primary cultured HERS/ERM cells possess a primitive stem/progenitor cell population that exhibits embryonic stem cell and epithelial markers $[57,65]$. Ex vivo-expanded ERM exhibited both bone marrow mesenchymal stem/progenitor cell- (heat shock protein-90b, CD44 and CD29) and epithelial cell-markers (epithelial membrane protein-1, cytokeratin-8, and E-cadherin) proving their stem/progenitor cell-like properties [66]. An ERM cell line was further successfully generated from human periodontium to be used for future research [67]. ERM cells when cocultured with dental pulp cells were differentiated into ameloblast-like cells and produced enamel-like tissues [68]. Immortalized odontogenic epithelial cells isolated from ERM expressed stem-cell-related genes and generated calcification foci when transplanted into immunocompromised mice [69].

Odontogenic epithelial stem cells (OEpSCs) were first observed in the continuously growing rodent incisors. They are of epithelial origin, interact reciprocally with the mesenchymal stem/progenitor cells of ectomesenchymal origin [70], and possess the ability to generate all the epithelial tissues of the tooth, including the enamel-forming ameloblastic layer [71-73]. In postnatal life, OEpSCs were identified in the epithelial rests of Malassez (ERM) usually present near the incomplete root ends; the junctional epithelium (JE) which surrounds the neck of teeth; the reduced enamel epithelium (REE) covering the newly erupting tooth; the dental lamina (DL) and its remnants, known as cell rests of Serres, in the retromolar area; and the remnants of DL in the gubernaculum cord (GC), found above any erupting tooth [74]. Various genes were recognized in OEpSCs, including Bmi, Sox2, Yap, ABCG2, Lgr5, Oct3/4, Gli1, and Lrig1 [72, 73, 75-78]. It was demonstrated that Sox $2+$ odontogenic epithelial stem cells are able to produce teeth. The odontogenic epithelial stem cell niche was proved to be regulated by Fgf10 [79, 80].

3.3. Scaffolds and Biodegradable Materials. To successfully culture a patterned enamel organ, it was found that a proper three-dimensional scaffold such as a collagen sponge in combination with feeder cells such as NIH $3 \mathrm{~T} 3$ mouse fibroblast cells should be present [81-83] to support and compensate for the epithelial-mesenchymal interactions that occur during early tooth formation [84]. Collagen sponge scaffolds and gels were demonstrated to help in cell attachment, proliferation, and differentiation as well as in the formation of calcified tissues [85]. Primary enamel organ cells cultured on feeder cells expressed many enamel proteins as kallikrein 4, ameloblastin, amelogenin, and matrix metalloproteinase (MMP) 20 [83]. Enamel organ epithelial (EOE) cells combined with dental pulp cells in scaffolds produced enamel with amelogenin expression in tall columnar epithelial cells found on enamel and dentin surfaces [48]. A threedimensional multilayered macroscale biomimetic coculture system, using chitosan and type I collagen was similarly seeded with mesenchymal-derived dental pulp stem cells and HAT-7 dental epithelial cells to simulate epithelialmesenchymal interactions. This system enabled the coculture of epithelial and mesenchymal cells, and the movement of the two cell types in various directions and $\mathrm{Ca}$ deposits were observed [86].

Still, available information is very limited and greatly diverse to distinguish the characteristics of each specific scaffold and its impact on possible stem/progenitor cellmediated enamel regenerative outcomes [87].

3.4. Signaling Molecules in Amelogenesis. Various signaling molecules were proposed to be involved in the epithelialmesenchymal interactions that occur during odontogenesis, including fibroblast growth factor (Fgf), sonic hedgehog $(\mathrm{SHH})$, wingless (Wnt), bone morphogenic protein (BMP), and transforming growth factor $\beta$ (TGF- $\beta$ ) [88, 89]. Activin, $\mathrm{BMP}$, and Fgf signals in the epithelial stem cell niche regulate enamel deposition in mice incisors [90]. Mesenchymal signals involved in ameloblast induction include TGF- $\beta 1$, BMP-4, and BMP-2 [91, 92]. SHH signaling preserves the stem cell niche present in the molar cervical loops [93]. FAK-YAP-mTOR signaling maintains the equilibrium between stem cell proliferation and differentiation towards ameloblast lineage [94]. BMP signaling was demonstrated to be crucial for ameloblast differentiation [91] and enamel formation [95]. Ectodysplasin (Eda), a signal found in primary and secondary enamel knots and the placodes of all ectodermal appendages, is considered a key regulator of 
ectodermal organ development, including molecules from vital signaling pathways such as SHH and Fgf20 [96]. In addition, $\mathrm{SHH}$ found in epithelial stratum intermedium cells support ameloblastic differentiation and maturation [97, 98]. Other epithelial signaling molecules that regulate ameloblasts are Wnt3, TGF- $\beta 1$, Follistatin, and Eda. Ameloblasts also express transcription factors such as Msx2 and Sp6 that have important roles in amelogenesis [99]. Regulating these molecules could help to generate ameloblast lineage precursors resembling odontogenic epithelial stem/progenitor cells that could be utilized in enamel regeneration approaches [6] (Table 1 and Figure 1).

\section{Dentin Regeneration}

4.1. Dentin Structure and Dentinogenesis. The pulp-dentin complex originates embryonically from the neural crest ectomesenchyme [100]. Odontoblasts are differentiated at the late bell stage of tooth development, and their major function is to secrete the extracellular dentin matrix components (ECM), followed by their mineralization, generating the primary dentin, the main bulk of the circumpulpal dentin matrix, and completing root formation. Secondary dentin is laid down as a physiological process throughout life, while tertiary dentin is generated at the pulp-dentin interface in response to environmental stimuli. Tertiary dentin might be reactionary (structurally similar to physiological dentin) or reparative (poorly organized, mainly atubular structure, with cells trapped within the matrix). Each type arises from two different populations of cells, original postmitotic odontoblasts and newly generated cells derived from the pulp (dental pulp stem/progenitor cells (DPSCs)), respectively $[101,102]$.

4.2. Cells. Aside from the attempts for enamel regeneration, stem/progenitor cell-based tissue engineering remains a promising modality for functional dentin regeneration [103-105]. A lineage-tracing study proved that new odontoblasts generated during reparative dentinogenesis in teeth come up from the perivascular cells identified by $\alpha$-smooth muscle actin $(\alpha \mathrm{SMA})$ expression. Furthermore, it was demonstrated that the progeny of the $\alpha \mathrm{SMA}+$ population scarcely participated in physiological dentin deposition [106]. Coimplantation of MSCs and ECs accelerated pulp healing with a complete dentin bridge formation [107]. Swine autologous dental pulp stem/progenitor cells (sDPSCs) transferred via hydrogel and transplanted into a mini swine root model showed that vascularized pulp-like tissue and a layer of newly deposited dentin (reparative dentin) were deposited along the canal walls with the creation of a dentin bridge-like structure [108]. A further in vivo study showed that iPSCs generated a pulp-like tissue with functional odontoblasts capable of producing tubular dentin-like structures [109]. In vitro investigation demonstrated that utilizing SHED in combination with different pulp capping materials stimulated proliferation, migration, and odontogenic-like phenotype differentiation of the cells [110].
4.3. Scaffolds and Biodegradable Materials. Several successful in vitro studies tested variable biomaterials to promote dentin regeneration. A biomembrane composed of a chitosan/collagen matrix embedded with calcium-aluminate microparticles proved to induce the differentiation of HDPCs into odontoblast-like cells, with the deposition of a significant amount of mineralized matrix [111]. Culturing of DPSCs onto human-treated dentin (hTD) regenerated dentin-like tissues $[112,113]$. Similarly, fibrin proved to enhance pulp-like tissue generation as well as odontoblast differentiation, with dentin sialoprotein expression [114].

An attempt to utilize a biodegradable collagen sponge as a delivery vehicle for molecules like MTA or other experimental small-molecule GSK3 inhibitors promoted tertiary dentin formation in deep dental lesions, following experimentally induced pulp exposure [115]. Ceramic scaffolds, such as calcium phosphates $(\mathrm{Ca} / \mathrm{P})$ and bioactive glasses or glass ceramics, were further tested. $\mathrm{Ca} / \mathrm{P}$ scaffolds contain tricalcium phosphate (TCP) or hydroxyapatite (HA), which are notably related to the mineralization of the matrix of the tooth [116]. Calcium hydroxide, Mineral Trioxide Aggregate (MTA), and Biodentine were reported to aid in the formation of the tertiary dentin [117]. Another in vitro study tested three capping materials, namely, mineral trioxide aggregate (MTA), calcium hydroxide $(\mathrm{CH})$, and Biodentine (BD), and proved that these materials are biocompatible and could stimulate proliferation, migration, and differentiation of SHED [110]. Nanofibrous spongy microspheres (NF-SMS), nanofibrous microspheres (NF-MS) without a pore structure, and conventional solid microspheres (S-MS) with neither nanofibers nor pore structure were further tested for dentin regeneration. The biodegradable and biocompatible poly(L-lactic acid) block-poly(L-lysine) were fabricated into the NF-SMS with interconnected pores, enhancing the proliferation and odontogenic differentiation of HDPSCs. NF-SMS provided superior dentin-like tissue formation compared to NF-MS or S-MS with a remarkable level of mineralization [118].

The application of biological printing combined with dental stem/progenitor cells employing clinical methods of 3D biofabrication and regeneration of dental tissues are the currently suggested alternative to classical dental restorations. The use of bioinks enabled the synthesis of scaffolds with precise, reproducible microarchitectures. Novel dentin-derived extracellular matrix (ECM) hybrid cell-laden hydrogel bioinks, synthesized from alginate and dentin matrix proteins were characterized and showed high printability and cell survival at different concentrations. Moreover, these hybrid hydrogels demonstrated the ability to be embedded with acid-soluble dentin molecules, enhancing odontogenic differentiation of SCAPs and effectively engineering the pulp-dentin complex [119].

4.4. Signaling Molecules. As previously mentioned, BMP-2 controls odontoblastic differentiation of dental pulp stem cells and transforming growth factor- $\beta$ (TGF- $\beta$ ) can stimulate odontoblast-like cell differentiation and DPSCmediated mineralization [23]. Also, platelet-derived growth factor (PDGFBB) and dentin-derived growth factors 


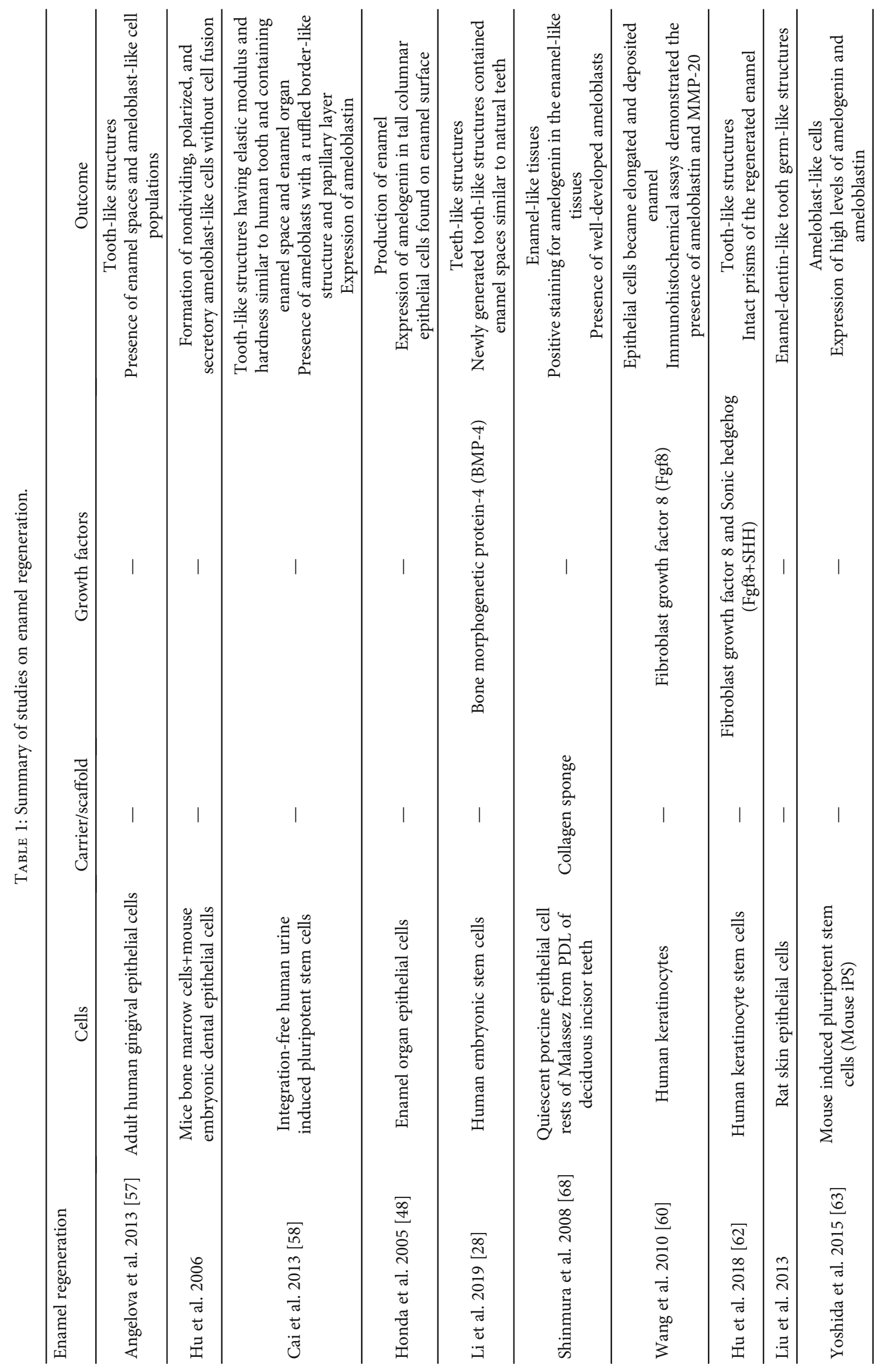




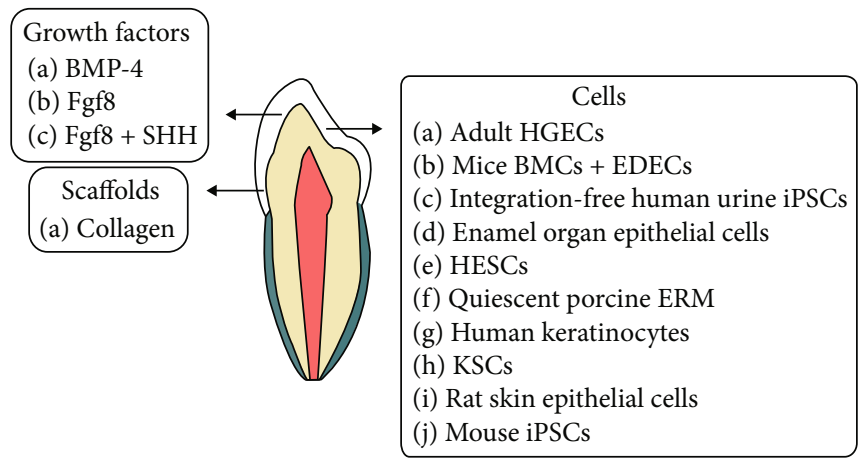

FIGURE 1: Diagram showing cells, growth factors, and scaffolds examined in the field of enamel regeneration.

(eDMP) proved to enhance HDPSC proliferation and odontoblastic differentiation, generating dentin-like mineralized tissues [120, 121]. G-CSF enhanced the proliferation and migration activity of stem/progenitor cells with dentin regeneration [122]. It was reported that the histone demethylation enzyme, lysine demethylase $1 \mathrm{~A}$ (KDM1A), can regulate the directed differentiation in odontogenic MSCs by forming KDM1A and PLOD2 (procollagene-lysine2, oxoglutarate5dioxygenase2) protein complex. It was reported that KDM1A in SCAP regulatory mechanisms of dynamic osteo/dentinogenic differentiation showed more diverse outcomes when applied in vitro than in vivo. However, in the final outcome of KDM1A inhibition, it promoted osteo/dentinogenesis in vivo [123]. Moreover, $\mathrm{H} 2 \mathrm{~S}$ proved to aid in the differentiation of DPSCs and dentin formation in vitro and in vivo via $\mathrm{Ca}^{2+}$ homeostasis and $\mathrm{Ca}^{2+}$ influx/GSK3 $\beta /$ (glycogen synthase kinase-3 $\beta$ ) $\beta$-catenin cascade response. Also, it was evident that $\beta$-catenin signaling plays crucial roles in dentin formation [124].

Simvastatin (SIM), a drug commonly used to treat hyperlipidemia, was further reported to enhance odontogenic differentiation and accelerate mineralized tissue formation and de novo dentin formation $[125,126]$. Combining SIM with canine DPSCs enhanced coronal pulp regeneration as well as dentin regeneration effectively and rapidly in beagle dogs. Small molecule inhibitors of glycogen synthase kinase 3 (GSK3) used in clinical trials for the treatment of neurological disorders such as Alzheimer's disease stimulated reparative dentine formation, with naturally generated new dentine at sites of damage $[115,127]$. Smaphorin 3A (Sema $3 \mathrm{~A})$ and its receptor Nrp1, usually expressed in rat dental pulp tissue and human DPSCs, were thought to be potent factors capable of inducing differentiation of DPSCs into odontoblasts. Sema3A application to dental pulp exposure sites in a rat model induced effective reparative dentin reconstruction and promoted the formation of an odontoblastic layer, dental tubules, and predentin [128] (Table 2 and Figure 2).

\section{Pulpal Tissue Regeneration}

5.1. Pulpal Tissue Structure. Dental pulp is the soft tissue located in the center of the tooth, and it is surrounded by dentin. The primary function of the pulp is formative; it gives rise to odontoblasts that form dentin. Odontoblasts are the most distinctive cells of the pulp. They form a single layer at the periphery and synthesize the matrix, which becomes mineralized and form dentin. As previously discussed, the pulp-dentin complex originates embryonically from the neural crest ectomesenchyme and constitutes physiologically and functionally a single unit, providing vital functions for tooth homeostasis [100].

The dental pulp is a richly vascularized and innervated connective tissue comprising heterogeneous cell populations, among which stem/progenitor cells are anticipated to constantly replenish odontoblasts to form secondary and tertiary/reparative dentin throughout adult life [101, 102, $129,130]$. Mesenchymal stem/progenitor cell transplantation into endodontically treated root canals was attempted to regenerate the damaged dental pulp-dentin complex [131]. Although most of the research conducted on stem/progenitor cell-mediated reparative/regenerative endodontics used animal models, initial human clinical data are available now.

5.2. Cells. Coimplementation of endothelial cells with MSCs induced the acceleration of pulp tissue regeneration/healing and dentin bridge formation together with the upregulation of proangiogenic factors and the formation of a more organized dental pulp-like tissue and a thicker dentin bridge [107, 131-133]. Porcine deciduous pulp stem/progenitor cells (PDPSCs) transplanted to repair pulp chamber roof defects in the premolars of swine showed that after 16 weeks they regenerated dentin-like structures and nearly completely restored pulp chamber roof defects [134]. MDPSC (mobilized dental pulp stem cell) transplantation into pulpectomized teeth with G-CSF resulted in pulp/dentin regeneration as was evident by electric pulp testing, magnetic resonance imaging, and cone beam computed tomography [135]. Transplanted autogenous HDPSCs (human dental pulp stem cells), regenerated, innervated, and vascularized dental pulpal tissue in 26 patients with root length completion and apical foramen closure. Following up patients with the implanted HDPSCs for 24 months did not demonstrate any adverse events [136]. DPSCs (dental pulp stem cells) isolated from an inflamed third molar after being extracted and cultured then inoculated in another tooth of the same patient showed a normal periapical area after 3-year follow-up using cone beam computed tomography [137]. 


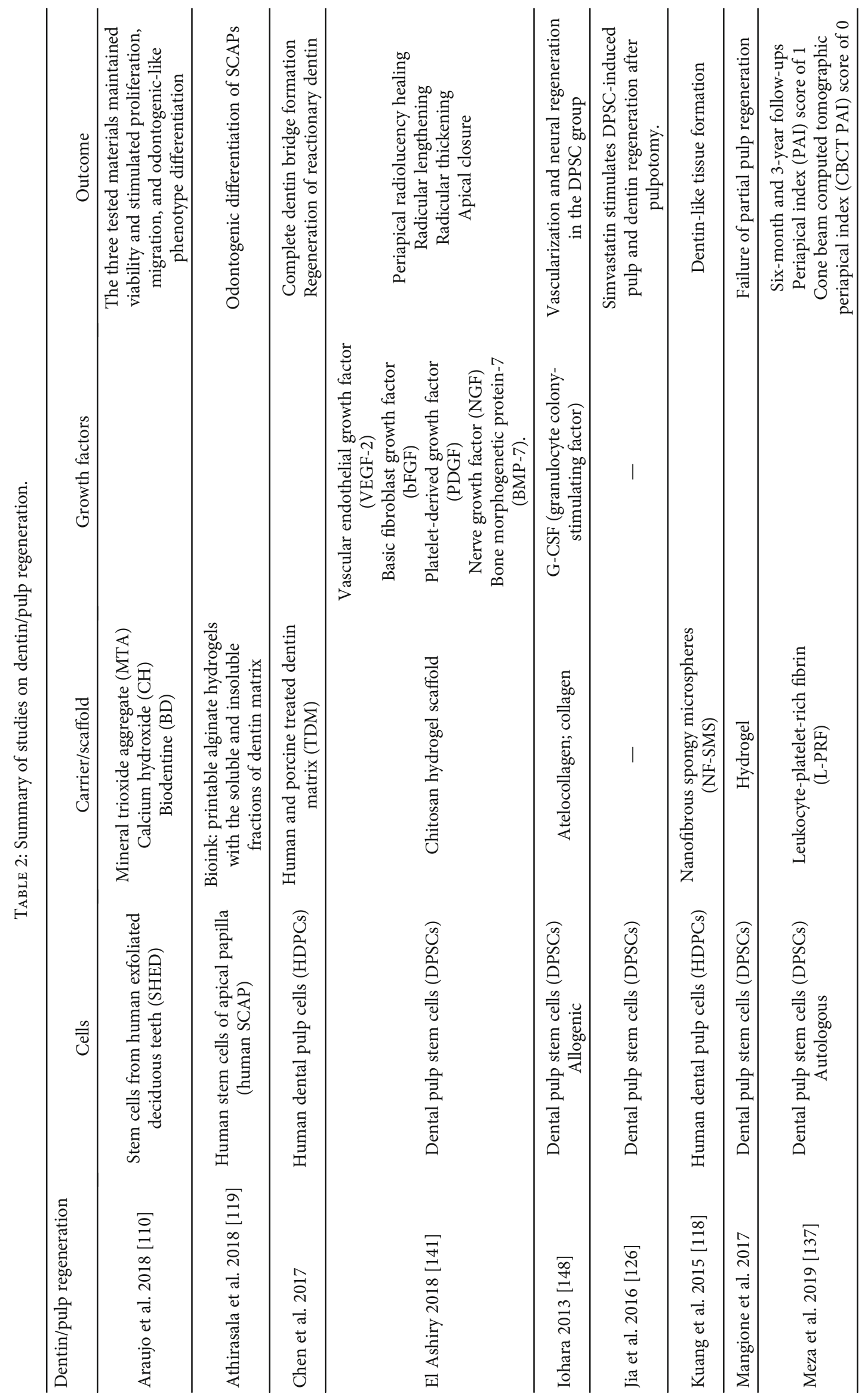




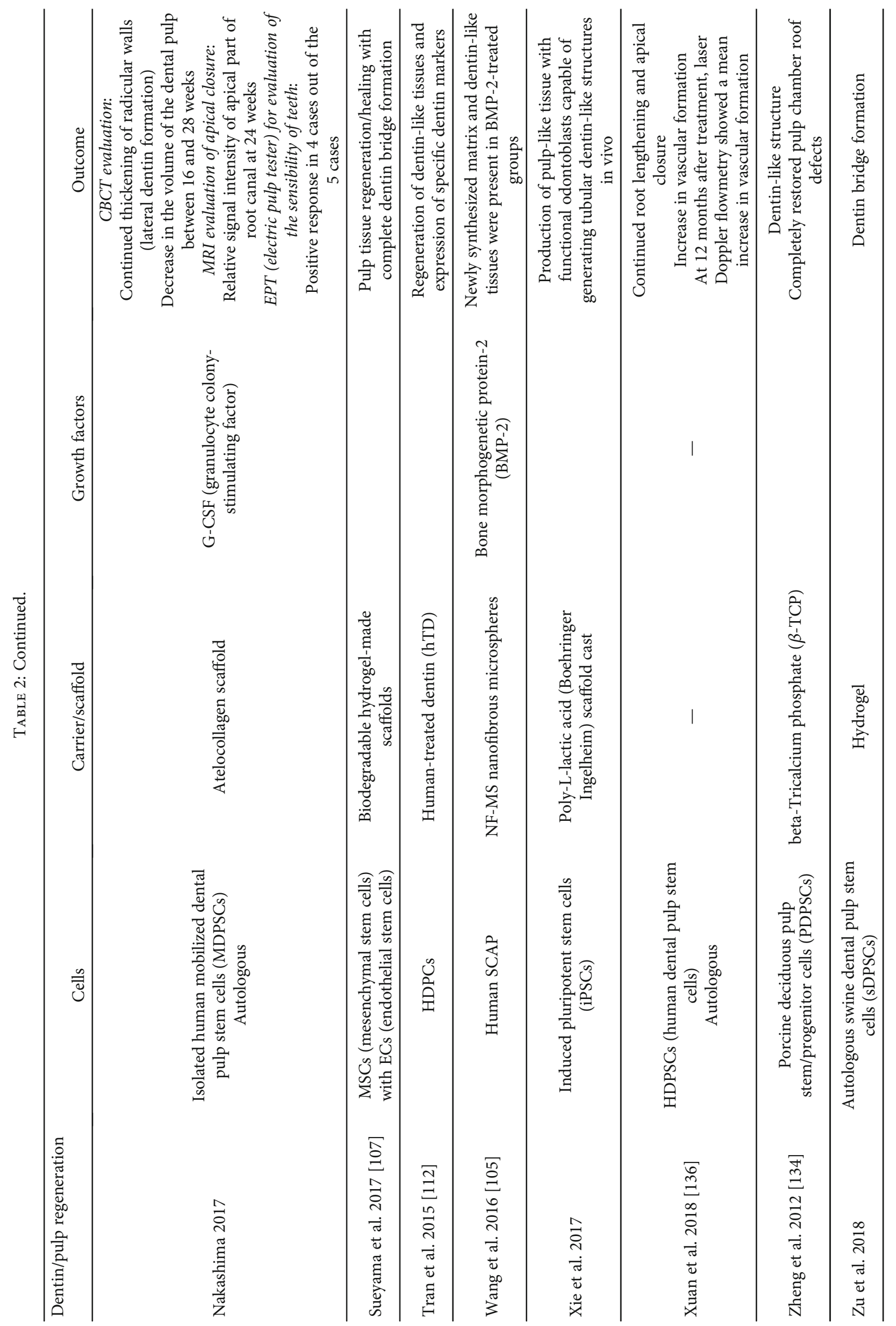




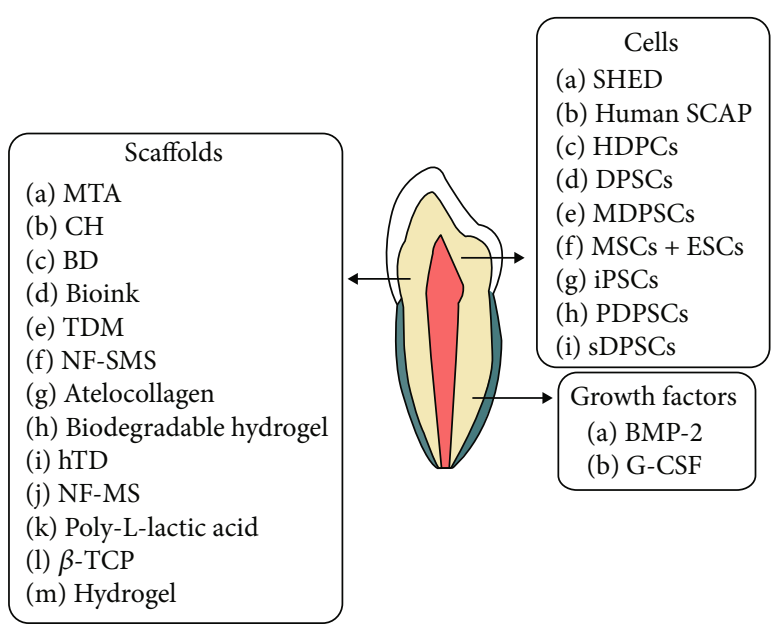

Figure 2: Diagram showing cells, growth factors, and scaffolds examined in the field of dentin regeneration.

Hence stem/progenitor cell transplantation holds a promising potential for dentin/pulp complex regeneration.

5.3. Scaffolds and Biodegradable Materials. Scaffolds harboring the appropriate growth/differentiation factors are very important for the success of pulpal tissue regeneration [132]. These scaffolds should mimic the natural pulpal microenvironment, providing the necessary structural signals, adhesion molecules, and pore sizes for homing, differentiation, and cellular phenotypic conversion, through permitting cell-matrix and cell-cell interactions [138]. Different scaffolds were used in different studies such as mineralized $\beta$-tricalcium phosphate carrier/scaffolds [134], injectable collagen $[122,139,140]$ and hydrogel-chitosan carriers [141], and gelatin sponge [126]. Platelet-rich fibrin (PRF), centrifuged from the patient's own blood samples, was suggested as a natural scaffold for pulpal tissue regeneration. PRF introduced inside the root canal allows cellular migration, cytokine enmeshment, and slow continuous release of cytokines such as platelet-derived growth factor, transforming growth factor beta 1, fibroblast growth factor, and vascular endothelial growth factor from 7 to 28 days, achieving the peak level on day 14 [142]. In addition, it provides a strong firm architecture and a specific 3-dimensional distribution of platelets and leukocytes [137]. A novel transplant consisting of cell-sheet fragments of DPSCs and PRF granules proved to regenerate pulp-dentin-like tissues in the root canal, both subcutaneously in nude mice and in the roots of canines. It induced a favorable regeneration of compact pulp-like tissues, and a remarkable deposition of regenerated dentin along the intracanal walls at 8 weeks postoperation was observed [143]. Still, the impact of the characteristics of carrier/scaffolds on the transplanted stem/progenitor cell-mediated regenerative outcomes are currently only partly elucidated [87].

5.4. Signaling Molecules. Similar to enamel and dentin formation, cytokines or signaling molecules participate in pulp regeneration through their ability to mobilize endogenous cells and to regulate the proliferation and differentiation of the stem/progenitor cells [144]. Signaling molecules have

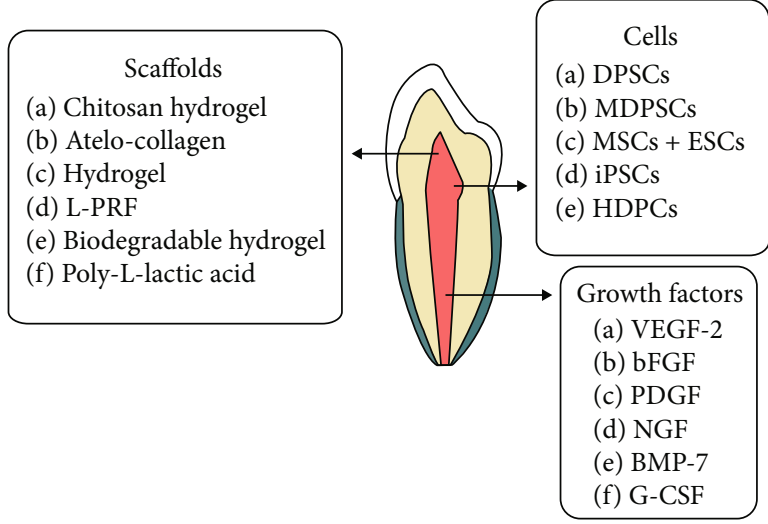

FIgURE 3: Diagram showing cells, growth factors, and scaffolds examined in the field of pulp regeneration.

been used and added to the scaffolds for proliferation, differentiation, and survival of stem/progenitor cells, with potentially important roles in signaling during pulp regeneration. Several studies suggested that many cytokines and growth factors were involved in promoting chemotaxis, proliferation, and differentiation of the stem/progenitor cells inside the root canal which led to generation of new tissues [145-147]. Transplantation of processed autologous dental pulp with growth factors (vascular endothelial growth factor-2 (VEGF-2), basic fibroblast growth factor (bFGF), platelet-derived growth factor (PDGF), nerve growth factor (NGF), and bone morphogenetic protein-7 (BMP-7)) embedded in a chitosan hydrogel scaffold was useful in regenerating pulp and dentin-like tissues in necrotic immature permanent teeth with apical periodontitis in dogs [141] with promising results. G-CSF in combination with DPSCs demonstrated pulpal tissue regeneration, vascularization, and nerve regeneration [148]. Basic fibroblast growth factor (bFGF) was demonstrated to be a potent homing/migration factor in pulp regeneration therapy similar to the influence of G-CSF [138]. Mobilized dental pulp stem cells and granulocyte colony-stimulating factor (G-CSF) with collagen transplanted into mature pulpectomized dogs' teeth completely filled the root canal with pulp-like tissue with large blood vessels and secondary dentin formation. However, MRI examination implied that the regenerated dentin might be undermineralized [149]. Another study revealed that stem cell factor (SCF) can accelerate cell homing and the maturation of the pulp-dentin complex in human immature teeth, as well as proliferation and odonto/osteogenic differentiation [150]. Still, the ideal constellation of growth/differentiation factors for functional pulpal regeneration remains largely unknown (Table 2 and Figure 3).

\section{Conclusion}

Stem/progenitor cell-based tissue engineering and bioprinting are promising approaches to protect the vitality and restore the integrity of dental tissues. Many attempts proved to be very promising, as reported in various in vitro studies, animal studies, and very few human trials. Despite the fact that the proposed biomaterials and techniques could be 
promising for future dental tissues' regeneration, still the complexity and the multicellular interactions naturally existing in dental structures represent great currently unsolved challenges. A clear set of universally accepted markers for the isolation and characterization of stem/progenitor cells and the development of serum and animal product-free culturing media for cell expansion are further major hurdles prior to considering stem/progenitor cell-based transplantation therapies for routine clinical application. Finally, the side effects of stem/progenitor transplantation should be clearly investigated, prior to becoming a clinical therapeutic reality in restorative dentistry.

\section{Abbreviations}

$\begin{array}{ll}\text { BMP-4/2/7: } & \text { Bone morphogenic protein-4/2/7 } \\ \text { Fgf8: } & \text { Fibroblast growth factor-8 } \\ \text { SHH: } & \text { Sonic hedgehog } \\ \text { HGECs: } & \text { Human gingival epithelial cells } \\ \text { BMCs: } & \text { Bone marrow cells } \\ \text { EDECs: } & \text { Embryonic dental epithelial cells } \\ \text { iPSCs: } & \text { Induced pluripotent stem cells } \\ \text { HESCs: } & \text { Human embryonic stem cells } \\ \text { ERM: } & \text { Epithelial rests of Malassez } \\ \text { KSCs: } & \text { Keratinocyte stem cells } \\ \text { MTA: } & \text { Mineral trioxide aggregate } \\ \text { CH: } & \text { Calcium hydroxide } \\ \text { BD: } & \text { Biodentine } \\ \text { TDM: } & \text { Treated dentin matrix } \\ \text { NF-SMS: } & \text { Nanofibrous spongy microspheres } \\ \text { hTD: } & \text { Human-treated dentin } \\ \text { NF-MS: } & \text { Nanofibrous microspheres } \\ \text { B-TCP: } & \text { } \text {-Tricalcium phosphate } \\ \text { SHED: } & \text { Stem cells from human exfoliated deciduous } \\ & \text { teeth } \\ \text { SCAP: } & \text { Stem cells from apical papilla } \\ \text { HDPSCs: } & \text { Human dental pulp stem cells } \\ \text { DPSCs: } & \text { Dental pulp stem cells } \\ \text { MDPSCs: } & \text { Mobilized dental pulp stem cells } \\ \text { MSCs: } & \text { Mesenchymal stem cells } \\ \text { ESCs: } & \text { Endothelial stem cells } \\ \text { PDPSCs: } & \text { Pig dental pulp stem cells } \\ \text { sDPSCs: } & \text { Swine dental pulp stem cells } \\ \text { G-CSF: } & \text { Granulocyte colony-stimulating factor } \\ \text { L-PRF: } & \text { Leucocyte-platelet-rich fibrin } \\ \text { VEGF-2: } & \text { Vascular endothelial growth factor-2 } \\ \text { bFGF: } & \text { Basic fibroblast growth factor } \\ \text { PDGF: } & \text { Platelet-derived growth factor } \\ \text { NGF: } & \text { Nerve growth factor. } \\ & \end{array}$

\section{Conflicts of Interest}

The authors declare that they have no conflicts of interest.

\section{References}

[1] F. C. Setzer and S. Kim, "Comparison of long-term survival of implants and endodontically treated teeth," Journal of Dental Research, vol. 93, no. 1, pp. 19-26, 2014.
[2] H. Zhu, Z. K. Guo, X. X. Jiang et al., “A protocol for isolation and culture of mesenchymal stem cells from mouse compact bone," Nature Protocols, vol. 5, no. 3, pp. 550-560, 2010.

[3] F.-J. Lv, R. S. Tuan, K. M. C. Cheung, and V. Y. L. Leung, "Concise review: the surface markers and identity of human mesenchymal stem cells," Stem Cells, vol. 32, no. 6, pp. 1408-1419, 2014.

[4] K. M. Fawzy El-Sayed, C. Dorfer, F. Fandrich, F. Gieseler, M. H. Moustafa, and H. Ungefroren, "Erratum to: Adult mesenchymal stem cells explored in the dental field," in Mesenchymal Stem Cells - Basics and Clinical Application II, vol. 130 of Advances in Biochemical Engineering/Biotechnology, , pp. 301-302, Springer, 2013.

[5] K. M. Fawzy El-Sayed, C. Dorfer, F. Fandrich, F. Gieseler, M. H. Moustafa, and H. Ungefroren, "Adult mesenchymal stem cells explored in the dental field," in Mesenchymal Stem Cells - Basics and Clinical Application II. Advances in Biochemical Engineering/Biotechnology, vol 130, pp. 89-103, Springer, Berlin, Heidelberg, 2013.

[6] A. Balic, "Biology explaining tooth repair and regeneration: a mini-review," Gerontology, vol. 64, no. 4, pp. 382-388, 2018.

[7] Q. Zhai, Z. Dong, W. Wang, B. Li, and Y. Jin, "Dental stem cell and dental tissue regeneration," Frontiers of Medicine, vol. 13, no. 2, pp. 152-159, 2019.

[8] R. Langer and J. P. Vacanti, “Tissue engineering," Science, vol. 260, no. 5110, pp. 920-926, 1993.

[9] D. Howard, L. D. Buttery, K. M. Shakesheff, and S. J. Roberts, "Tissue engineering: strategies, stem cells and scaffolds," Journal of Anatomy, vol. 213, no. 1, pp. 66-72, 2008.

[10] A. Slaughter and L. K. Evans, "Culturally sensitive oral health educational materials for older African Americans," Journal of Health Care for the Poor and Underserved, vol. 18, no. 4, pp. 868-886, 2007.

[11] A. H. Yen and P. T. Sharpe, "Stem cells and tooth tissue engineering," Cell and Tissue Research, vol. 331, no. 1, pp. 359-372, 2008.

[12] P. M. Taylor, "Biological matrices and bionanotechnology," Philosophical Transactions of the Royal Society B: Biological Sciences, vol. 362, no. 1484, pp. 1313-1320, 2007.

[13] U. A. Stock and J. P. Vacanti, "Tissue engineering: current state and prospects," Annual Review of Medicine, vol. 52, no. 1, pp. 443-451, 2001.

[14] J. A. Thomson, J. Itskovitz-Eldor, S. S. Shapiro et al., "Embryonic stem cell lines derived from human blastocysts," Science, vol. 282, no. 5391, pp. 1145-1147, 1998.

[15] R. McKay, "Stem cells-hype and hope," Nature, vol. 406, no. 6794, pp. 361-364, 2000.

[16] A. Vats, N. S. Tolley, J. M. Polak, and L. D. K. Buttery, "Stem cells: sources and applications," Clinical Otolaryngology and Allied Sciences, vol. 27, no. 4, pp. 227-232, 2002.

[17] B. Hashemi-Beni, M. Khoroushi, M. R. Foroughi, S. Karbasi, and A. A. Khademi, "Tissue engineering: Dentin - pulp complex regeneration approaches (A review)," Tissue and Cell, vol. 49, no. 5, pp. 552-564, 2017.

[18] U. Ripamonti, "Soluble, insoluble and geometric signals sculpt the architecture of mineralized tissues," Journal of Cellular and Molecular Medicine, vol. 8, no. 2, pp. 169-180, 2004.

[19] M. Brittberg, A. Lindahl, A. Nilsson, C. Ohlsson, O. Isaksson, and L. Peterson, "Treatment of deep cartilage defects in the knee with autologous chondrocyte transplantation," The 
New England Journal of Medicine, vol. 331, no. 14, pp. 889895, 1994.

[20] J. B. Richardson, B. Caterson, E. H. Evans, B. A. Ashton, and S. Roberts, "Repair of human articular cartilage after implantation of autologous chondrocytes," The Journal of Bone and Joint Surgery. British Volume, vol. 81-B, no. 6, pp. 1064-1068, 1999.

[21] M. Goldberg and A. J. Smith, "Cells and extracellular matrices of dentin and pulp: a biological basis for repair and tissue engineering," Critical Reviews in Oral Biology \& Medicine, vol. 15, no. 1, pp. 13-27, 2004.

[22] C. Du and J. Moradian-Oldak, "Tooth regeneration: challenges and opportunities for biomedical material research," Biomedical Materials, vol. 1, no. 1, pp. R10-R17, 2006.

[23] M. Oshima and T. Tsuji, "Functional tooth regenerative therapy: tooth tissue regeneration and whole-tooth replacement," Odontology, vol. 102, no. 2, pp. 123-136, 2014.

[24] C. Kitamura, T. Nishihara, M. Terashita, Y. Tabata, and A. Washio, "Local regeneration of dentin-pulp complex using controlled release of fgf- 2 and naturally derived sponge-like scaffolds," International Journal of Dentistry, vol. 2012, Article ID 190561, 8 pages, 2012.

[25] R. Goldman, "Growth factors and chronic wound healing: past, present, and future," Advances in Skin \& Wound Care, vol. 17, no. 1, pp. 24-35, 2004.

[26] A. T. Grazul-Bilska, M. L. Johnson, J. J. Bilski et al., "Wound healing: the role of growth factors," Drugs of Today, vol. 39, no. 10, pp. 787-800, 2003.

[27] M. Atanasova and A. Whitty, "Understanding cytokine and growth factor receptor activation mechanisms," Critical Reviews in Biochemistry and Molecular Biology, vol. 47, no. 6, pp. 502-530, 2012.

[28] Q. Li, S. Zhang, Y. Sui, X. Fu, Y. Li, and S. Wei, "Sequential stimulation with different concentrations of BMP4 promotes the differentiation of human embryonic stem cells into dental epithelium with potential for tooth formation," Stem Cell Research \& Therapy, vol. 10, no. 1, p. 276, 2019.

[29] R. E. Robinson, “The organic constituent of enamel," Tufts Dental Outlook, vol. 19, no. 4, pp. 5-10, 1945.

[30] M. T. Jansen, "Serial sections of undecalcified enamel," Journal of Dental Research, vol. 25, no. 5, pp. 355-365, 1946.

[31] B. P. Reed and C. I. Reed, "Electron microscopy of erythrocytes from dog blood," Federation Proceedings, vol. 6, 1, Part 2, p. 185, 1947.

[32] R. G. Agnew, “Observations on enamel formation," Journal of Dental Research, vol. 26, no. 6, p. 462, 1947.

[33] A. Szczes, L. Holysz, and E. Chibowski, "Synthesis of hydroxyapatite for biomedical applications," Advances in Colloid and Interface Science, vol. 249, pp. 321-330, 2017.

[34] S. C. Loo, T. Moore, B. Banik, and F. Alexis, "Biomedical applications of hydroxyapatite nanoparticles," Current Pharmaceutical Biotechnology, vol. 11, no. 4, pp. 333-342, 2010.

[35] W. Habraken, P. Habibovic, M. Epple, and M. Bohner, "Calcium phosphates in biomedical applications: materials for the future?," Materials Today, vol. 19, no. 2, pp. 69-87, 2016.

[36] M. Nasr-Esfahani and S. Fekri, "Alumina/TiO ${ }_{2} /$ hydroxyapatite interface nanostructure composite filters as efficient photocatalysts for the purification of air," Reaction Kinetics, Mechanisms and Catalysis, vol. 107, no. 1, pp. 89-103, 2012.
[37] M. Pandya and T. G. H. Diekwisch, "Enamel biomimetics-fiction or future of dentistry," International Journal of Oral Science, vol. 11, no. 1, article 38, p. 8, 2019.

[38] T. A. Mitsiadis and D. Graf, "Cell fate determination during tooth development and regeneration," Birth Defects Research Part C: Embryo Today: Reviews, vol. 87, no. 3, pp. 199-211, 2009.

[39] J. Kirkham, S. J. Brookes, T. G. H. Diekwisch, H. C. Margolis, A. Berdal, and M. J. Hubbard, "Enamel research: priorities and future directions," Frontiers in Physiology, vol. 8, p. 513, 2017.

[40] O. D. Klein, O. Duverger, W. Shaw et al., "Meeting report: a hard look at the state of enamel research," International Journal of Oral Science, vol. 9, no. 11, article e3, 2017.

[41] A. G. Fincham, J. Moradian-Oldak, and J. P. Simmer, "The structural biology of the developing dental enamel matrix," Journal of Structural Biology, vol. 126, no. 3, pp. 270-299, 1999.

[42] P. Moffatt, C. E. Smith, R. St-Arnaud, D. Simmons, J. T. Wright, and A. Nanci, "Cloning of rat amelotin and localization of the protein to the basal lamina of maturation stage ameloblasts and junctional epithelium," Biochemical Journal, vol. 399, no. 1, pp. 37-46, 2006.

[43] P. Moffatt, C. E. Smith, R. St-Arnaud, and A. Nanci, "Characterization of apin, a secreted protein highly expressed in tooth-associated epithelia," Journal of Cellular Biochemistry, vol. 103, no. 3, pp. 941-956, 2008.

[44] C. Nishio, R. Wazen, P. Moffatt, and A. Nanci, "Expression of odontogenic ameloblast-associated and amelotin proteins in the junctional epithelium," Periodontol 2000, vol. 63, no. 1, pp. 59-66, 2013.

[45] K. Iwasaki, E. Bajenova, E. Somogyi-Ganss et al., "Amelotin-a novel secreted, ameloblast-specific protein," Journal of Dental Research, vol. 84, no. 12, pp. 1127-1132, 2005.

[46] J. Moradian-Oldak, "Protein-mediated enamel mineralization," Frontiers in Bioscience, vol. 17, no. 7, pp. 1996-2023, 2012.

[47] J. M. ten Cate, "Review on fluoride, with special emphasis on calcium fluoride mechanisms in caries prevention," European Journal of Oral Sciences, vol. 105, 5, Part 2, pp. 461-465, 1997.

[48] M. J. Honda, Y. Sumita, H. Kagami, and M. Ueda, "Histological and immunohistochemical studies of tissue engineered odontogenesis," Archives of Histology and Cytology, vol. 68, no. 2, pp. 89-101, 2005.

[49] X. Chatzistavrou, S. Papagerakis, P. X. Ma, and P. Papagerakis, "Innovative approaches to regenerate enamel and dentin," International Journal of Dentistry, vol. 2012, Article ID 856470, 5 pages, 2012.

[50] J. P. Simmer, A. S. Richardson, Y. Y. Hu, C. E. Smith, and J. Ching-Chun $\mathrm{Hu}$, "A post-classical theory of enamel biomineralization... and why we need one," International Journal of Oral Science, vol. 4, no. 3, pp. 129-134, 2012.

[51] V. Uskokovic, "Prospects and pits on the path of biomimetics: the case of tooth enamel," Journal of Biomimetics, Biomaterials and Tissue Engineering, vol. 8, pp. 45-78, 2010.

[52] Q. Ruan and J. Moradian-Oldak, "Amelogenin and enamel biomimetics," Journal of Materials Chemistry B, vol. 3, pp. 3112-3129, 2015.

[53] S. Mann, "The biomimetics of enamel: a paradigm for organized biomaterials synthesis," in Ciba Foundation 
Symposium 205 - Dental Enamel Ciba Foundation Symposium 205, pp. 261-269, John Wiley \& Sons Ltd., 1997.

[54] M. Pandya, T. Lin, L. Li et al., "Posttranslational amelogenin processing and changes in matrix assembly during enamel development," Frontiers in Physiology, vol. 8, p. 790, 2017.

[55] M. K. Pugach, C. Suggs, Y. Li et al., "M180 amelogenin processed by MMP20 is sufficient for decussating murine enamel," Journal of Dental Research, vol. 92, no. 12, pp. 1118-1122, 2013.

[56] Jayasudha, Baswaraj, H. K. Navin, and K. B. Prasanna, "Enamel regeneration-current progress and challenges," Journal of Clinical and Diagnostic Research, vol. 8, no. 9, pp. Ze06-Ze09, 2014.

[57] A. Angelova Volponi, M. Kawasaki, and P. T. Sharpe, "Adult human gingival epithelial cells as a source for whole-tooth bioengineering," Journal of Dental Research, vol. 92, no. 4, pp. 329-334, 2013.

[58] J. Cai, Y. Zhang, P. Liu et al., "Generation of tooth-like structures from integration-free human urine induced pluripotent stem cells," Cell Regeneration, vol. 2, no. 1, 2013.

[59] X. Hu, C. Lin, B. Shen et al., "Conserved odontogenic potential in embryonic dental tissues," Journal of Dental Research, vol. 93, no. 5, pp. 490-495, 2014.

[60] B. Wang, L. Li, S. du et al., "Induction of human keratinocytes into enamel-secreting ameloblasts," Developmental Biology, vol. 344, no. 2, pp. 795-799, 2010.

[61] L. W. Zheng, L. Linthicum, P. K. DenBesten, and Y. Zhang, "The similarity between human embryonic stem cellderived epithelial cells and ameloblast-lineage cells," International Journal of Oral Science, vol. 5, no. 1, pp. 1-6, 2013.

[62] X. Hu, J. W. Lee, X. Zheng et al., "Efficient induction of functional ameloblasts from human keratinocyte stem cells," Stem Cell Research \& Therapy, vol. 9, no. 1, p. 126, 2018.

[63] K. Yoshida, J. Sato, R. Takai et al., "Differentiation of mouse iPS cells into ameloblast-like cells in cultures using medium conditioned by epithelial cell rests of Malassez and gelatincoated dishes," Medical Molecular Morphology, vol. 48, no. 3, pp. 138-145, 2015.

[64] C. D. Fong and L. Hammarstrom, "Expression of amelin and amelogenin in epithelial root sheath remnants of fully formed rat molars," Oral Surgery, Oral Medicine, Oral Pathology, Oral Radiology, and Endodontics, vol. 90, no. 2, pp. 218223, 2000.

[65] H. Nam, J. Kim, J. Park et al., "Expression profile of the stem cell markers in human Hertwig's epithelial root sheath/epithelial rests of Malassez cells," Molecules and Cells, vol. 31, no. 4, pp. 355-360, 2011.

[66] J. Xiong, K. Mrozik, S. Gronthos, and P. M. Bartold, "Epithelial cell rests of Malassez contain unique stem cell populations capable of undergoing epithelial-mesenchymal transition," Stem Cells and Development, vol. 21, no. 11, pp. 2012-2025, 2012.

[67] H. Nam, J. H. Kim, J. W. Kim et al., "Establishment of Hertwig's epithelial root sheath/epithelial rests of Malassez cell line from human periodontium," Molecules and Cells, vol. 37, no. 7, pp. 562-567, 2014.

[68] Y. Shinmura, S. Tsuchiya, K. Hata, and M. J. Honda, "Quiescent epithelial cell rests of Malassez can differentiate into ameloblast-like cells," Journal of Cellular Physiology, vol. 217, no. 3, pp. 728-738, 2008.
[69] T. Tsunematsu, N. Fujiwara, M. Yoshida et al., "Human odontogenic epithelial cells derived from epithelial rests of Malassez possess stem cell properties," Laboratory Investigation, vol. 96, no. 10, pp. 1063-1075, 2016.

[70] C. E. Smith and H. Warshawsky, "Cellular renewal in the enamel organ and the odontoblast layer of the rat incisor as followed by radioautography using ${ }^{3} \mathrm{H}$-thymidine," The Anatomical Record, vol. 183, no. 4, pp. 523-561, 1975.

[71] H. Harada, P. Kettunen, H. S. Jung, T. Mustonen, Y. A. Wang, and I. Thesleff, "Localization of putative stem cells in dental epithelium and their association with Notch and FGF signaling," Journal of Cell Biology, vol. 147, no. 1, pp. 105-120, 1999.

[72] E. Juuri, K. Saito, L. Ahtiainen et al., "Sox2+ stem cells contribute to all epithelial lineages of the tooth via Sfrp5+ progenitors," Developmental Cell, vol. 23, no. 2, pp. 317-328, 2012.

[73] B. Biehs, J. K. Hu, N. B. Strauli et al., "BMI1 represses Ink4a/Arf and Hox genes to regulate stem cells in the rodent incisor," Nature Cell Biology, vol. 15, no. 7, pp. 846-852, 2013.

[74] S. Padma Priya, A. Higuchi, S. Abu Fanas et al., "Odontogenic epithelial stem cells: hidden sources," Laboratory Investigation, vol. 95, no. 12, pp. 1344-1352, 2015.

[75] L. Li, H. J. Kwon, H. Harada, H. Ohshima, S. W. Cho, and H. S. Jung, "Expression patterns of ABCG2, Bmi-1, Oct-3/4, and Yap in the developing mouse incisor," Gene Expression Patterns, vol. 11, no. 3-4, pp. 163-170, 2011.

[76] K. Seidel, C. P. Ahn, D. Lyons et al., "Hedgehog signaling regulates the generation of ameloblast progenitors in the continuously growing mouse incisor," Development, vol. 137, no. 22, pp. 3753-3761, 2010.

[77] M. Suomalainen and I. Thesleff, "Patterns of Wnt pathway activity in the mouse incisor indicate absence of $\mathrm{Wnt} / \beta$ catenin signaling in the epithelial stem cells," Developmental Dynamics, vol. 239, no. 1, pp. 364-372, 2010.

[78] K. Seidel, P. Marangoni, C. Tang et al., "Resolving stem and progenitor cells in the adult mouse incisor through gene co-expression analysis," eLife, vol. 6, 2017.

[79] T. Yokohama-Tamaki, H. Ohshima, N. Fujiwara et al., "Cessation of Fgf10 signaling, resulting in a defective dental epithelial stem cell compartment, leads to the transition from crown to root formation," Development, vol. 133, no. 7, pp. 1359-1366, 2006.

[80] H. Harada, T. Toyono, K. Toyoshima et al., "FGF10 maintains stem cell compartment in developing mouse incisors," Development, vol. 129, no. 6, pp. 1533-1541, 2002.

[81] M. J. Honda, T. Shimodaira, T. Ogaeri, Y. Shinohara, K. Hata, and M. Ueda, "A novel culture system for porcine odontogenic epithelial cells using a feeder layer," Archives of Oral Biology, vol. 51, no. 4, pp. 282-290, 2006.

[82] M. J. Honda, Y. Shinmura, and Y. Shinohara, "Enamel tissue engineering using subcultured enamel organ epithelial cells in combination with dental pulp cells," Cells Tissues Organs, vol. 189, no. 1-4, pp. 261-267, 2009.

[83] A. Matsumoto, H. Harada, M. Saito, and A. Taniguchi, "Induction of enamel matrix protein expression in an ameloblast cell line co-cultured with a mesenchymal cell line in vitro," In Vitro Cellular \& Developmental Biology - Animal, vol. 47, no. 1, pp. 39-44, 2011.

[84] I. Thesleff, "Epithelial-mesenchymal signalling regulating tooth morphogenesis," Journal of Cell Science, vol. 116, Part 9, pp. 1647-1648, 2003. 
[85] Y. Sumita, M. J. Honda, T. Ohara et al., "Performance of collagen sponge as a 3-D scaffold for tooth-tissue engineering," Biomaterials, vol. 27, no. 17, pp. 3238-3248, 2006.

[86] S. Ravindran, Y. Song, and A. George, "Development of three-dimensional biomimetic scaffold to study epithelialmesenchymal interactions," Tissue Engineering Part A, vol. 16, no. 1, pp. 327-342, 2010.

[87] K. A. Fukushima, M. M. Marques, T. K. Tedesco et al., "Screening of hydrogel-based scaffolds for dental pulp regeneration-a systematic review," Archives of Oral Biology, vol. 98, pp. 182-194, 2019.

[88] M. Bei, "Molecular genetics of tooth development," Current Opinion in Genetics \& Development, vol. 19, no. 5, pp. 504510, 2009.

[89] M. Tummers and I. Thesleff, "The importance of signal pathway modulation in all aspects of tooth development," Journal of Experimental Zoology Part B: Molecular and Developmental Evolution, vol. 312B, no. 4, pp. 309-319, 2009.

[90] X. P. Wang, M. Suomalainen, S. Felszeghy et al., “An integrated gene regulatory network controls stem cell proliferation in teeth," PLoS Biology, vol. 5, no. 6, article e159, 2007.

[91] X. P. Wang, M. Suomalainen, C. J. Jorgez, M. M. Matzuk, S. Werner, and I. Thesleff, "Follistatin regulates enamel patterning in mouse incisors by asymmetrically inhibiting BMP signaling and ameloblast differentiation," Developmental Cell, vol. 7, no. 5, pp. 719-730, 2004.

[92] R. Coin, Y. Haikel, and J. V. Ruch, "Effects of apatite, transforming growth factor $\beta-1$, bone morphogenetic protein-2 and interleukin-7 on ameloblast differentiation in vitro," European Journal of Oral Sciences, vol. 107, no. 6, pp. 487495, 1999.

[93] J. Li, J. Feng, Y. Liu et al., "BMP-SHH signaling network controls epithelial stem cell fate via regulation of its niche in the developing tooth," Developmental Cell, vol. 33, no. 2, pp. 125$135,2015$.

[94] J. K.-H. Hu, W. du, S. J. Shelton, M. C. Oldham, C. M. DiPersio, and O. D. Klein, "An FAK-YAP-mTOR signaling axis regulates stem cell-based tissue renewal in mice," Cell Stem Cell, vol. 21, no. 1, pp. 91-106.e6, 2017.

[95] M. V. Plikus, M. Zeichner-David, J. A. Mayer et al., "Morphoregulation of teeth: modulating the number, size, shape and differentiation by tuning Bmp activity," Evolution Development, vol. 7, no. 5, pp. 440-457, 2005.

[96] M. L. Mikkola, "Molecular aspects of hypohidrotic ectodermal dysplasia," American journal of medical genetics Part A, vol. 149A, no. 9, pp. 2031-2036, 2009.

[97] H. R. Dassule, P. Lewis, M. Bei, R. Maas, and A. P. McMahon, "Sonic hedgehog regulates growth and morphogenesis of the tooth," Development, vol. 127, no. 22, pp. 4775-4785, 2000.

[98] A. Gritli-Linde, M. Bei, R. Maas, X. M. Zhang, A. Linde, and A. P. McMahon, "Shh signaling within the dental epithelium is necessary for cell proliferation, growth and polarization," Development, vol. 129, no. 23, pp. 5323-5337, 2002.

[99] M. Bei, "Molecular genetics of ameloblast cell lineage," Journal of Experimental Zoology Part B: Molecular and Developmental Evolution, vol. 312B, no. 5, pp. 437-444, 2009.

[100] J. J. Mao and D. J. Prockop, "Stem cells in the face: tooth regeneration and beyond," Cell Stem Cell, vol. 11, no. 3, pp. 291-301, 2012.

[101] A. J. Smith, N. Cassidy, H. Perry, C. Begue-Kirn, J. V. Ruch, and H. Lesot, "Reactionary dentinogenesis," International
Journal of Developmental Biology, vol. 39, no. 1, pp. 273280, 2003 .

[102] A. J. Sloan and R. J. Waddington, "Dental pulp stem cells: what, where, how?," International Journal of Paediatric Dentistry, vol. 19, no. 1, pp. 61-70, 2009.

[103] T. Guo, Y. Li, G. Cao et al., "Fluorapatite-modified scaffold on dental pulp stem cell mineralization," Journal of Dental Research, vol. 93, no. 12, pp. 1290-1295, 2014.

[104] M. Murakami, Y. Hayashi, K. Iohara, Y. Osako, Y. Hirose, and M. Nakashima, "Trophic effects and regenerative potential of mobilized mesenchymal stem cells from bone marrow and adipose tissue as alternative cell sources for pulp/dentin regeneration," Cell Transplantation, vol. 24, no. 9, pp. 1753-1765, 2015.

[105] W. Wang, M. Dang, Z. Zhang et al., "Dentin regeneration by stem cells of apical papilla on injectable nanofibrous microspheres and stimulated by controlled BMP-2 release," Acta Biomaterialia, vol. 36, pp. 63-72, 2016.

[106] I. Vidovic, A. Banerjee, R. Fatahi et al., " $\alpha$ SMA-expressing perivascular cells represent dental pulp progenitors in vivo," Journal of Dental Research, vol. 96, no. 3, pp. 323-330, 2017.

[107] Y. Sueyama, T. Kaneko, T. Ito, R. Kaneko, and T. Okiji, "Implantation of endothelial cells with mesenchymal stem cells accelerates dental pulp tissue regeneration/healing in pulpotomized rat molars," Journal of Endodontics, vol. 43, no. 6, pp. 943-948, 2017.

[108] X. Zhu, J. Liu, Z. Yu et al., "A miniature swine model for stem cell-based de novo regeneration of dental pulp and dentinlike tissue," Tissue Engineering Part C: Methods, vol. 24, no. 2, pp. 108-120, 2018.

[109] H. Xie, N. Dubey, W. Shim et al., "Functional odontoblasticlike cells derived from human iPSCs," Journal of Dental Research, vol. 97, no. 1, pp. 77-83, 2018.

[110] L. B. Araújo, L. Cosme-Silva, A. P. Fernandes et al., "Effects of mineral trioxide aggregate, Biodentine ${ }^{\mathrm{TM}}$ and calcium hydroxide on viability, proliferation, migration and differentiation of stem cells from human exfoliated deciduous teeth," Journal of Applied Oral Science, vol. 26, 2018.

[111] D. G. Soares, H. L. Rosseto, F. G. Basso, D. S. Scheffel, J. Hebling, and C. A. de Souza Costa, "Chitosan-collagen biomembrane embedded with calcium-aluminate enhances dentinogenic potential of pulp cells," Brazilian Oral Research, vol. 30 , no. 1,2016

[112] H. L. B. Tran and V. N. Doan, "Human dental pulp stem cells cultured onto dentin derived scaffold can regenerate dentinlike tissue in vivo," Cell and Tissue Banking, vol. 16, no. 4, pp. 559-568, 2015.

[113] A. Aliasghari, M. Rabbani Khorasgani, S. Vaezifar, F. Rahimi, H. Younesi, and M. Khoroushi, "Evaluation of antibacterial efficiency of chitosan and chitosan nanoparticles on cariogenic streptococci: an in vitro study," Iranian Journal of Microbiology, vol. 8, no. 2, pp. 93-100, 2016.

[114] K. M. Galler, F. P. Brandl, S. Kirchhof et al., "Suitability of different natural and synthetic biomaterials for dental pulp tissue engineering," Tissue Engineering Part A, vol. 24, no. 3-4, pp. 234-244, 2018.

[115] V. C. M. Neves, R. Babb, D. Chandrasekaran, and P. T. Sharpe, "Promotion of natural tooth repair by small molecule GSK3 antagonists," Scientific Reports, vol. 7, no. 1, article 39654, 2017. 
[116] M. Montazeri, S. Karbasi, M. R. Foroughi, A. Monshi, and R. Ebrahimi-Kahrizsangi, "Evaluation of mechanical property and bioactivity of nano-bioglass $45 \mathrm{~S} 5$ scaffold coated with poly-3-hydroxybutyrate," Journal of Materials Science: Materials in Medicine, vol. 26, no. 2, p. 62, 2015.

[117] A. Nowicka, M. Lipski, M. Parafiniuk et al., "Response of human dental pulp capped with biodentine and mineral trioxide aggregate," Journal of Endodontics, vol. 39, no. 6, pp. 743-747, 2013.

[118] R. Kuang, Z. Zhang, X. Jin et al., "Nanofibrous spongy microspheres enhance odontogenic differentiation of human dental pulp stem cells," Advanced Healthcare Materials, vol. 4, no. 13, pp. 1993-2000, 2015.

[119] A. Athirasala, A. Tahayeri, G. Thrivikraman et al., "A dentinderived hydrogel bioink for 3D bioprinting of cell laden scaffolds for regenerative dentistry," Biofabrication, vol. 10, no. 2, article 024101, 2018.

[120] M. Zhang, F. Jiang, X. Zhang et al., "The effects of plateletderived growth factor-BB on human dental pulp stem cells mediated dentin-pulp complex regeneration," Stem Cells Translational Medicine, vol. 6, no. 12, pp. 2126-2134, 2017.

[121] M. Widbiller, R. B. Driesen, A. Eidt et al., "Cell homing for pulp tissue engineering with endogenous dentin matrix proteins," Journal of Endodontics, vol. 44, no. 6, pp. 956962.e2, 2018.

[122] K. Iohara, M. Murakami, K. Nakata, and M. Nakashima, "Age-dependent decline in dental pulp regeneration after pulpectomy in dogs," Experimental Gerontology, vol. 52, pp. 39-45, 2014.

[123] L. Wang, H. Yang, X. Lin et al., "KDM1A regulated the osteo/dentinogenic differentiation process of the stem cells of the apical papilla via binding with PLOD2," Cell Proliferation, vol. 51, no. 4, article e12459, 2018.

[124] R. Yang, Y. Liu, T. Yu et al., "Hydrogen sulfide maintains dental pulp stem cell function via TRPV1-mediated calcium influx," Cell Death Discovery, vol. 4, no. 1, p. 69, 2018.

[125] Y. Okamoto, W. Sonoyama, M. Ono et al., "Simvastatin induces the odontogenic differentiation of human dental pulp stem cells in vitro and in vivo," Journal of Endodontics, vol. 35, no. 3, pp. 367-372, 2009.

[126] W. Jia, Y. Zhao, J. Yang et al., "Simvastatin promotes dental pulp stem cell-induced coronal pulp regeneration in pulpotomized teeth," Journal of Endodontics, vol. 42, no. 7, pp. 1049-1054, 2016.

[127] T. del Ser, K. C. Steinwachs, H. J. Gertz et al., "Treatment of Alzheimer's disease with the GSK-3 inhibitor tideglusib: a pilot study," Journal of Alzheimer's Disease, vol. 33, no. 1, pp. 205-215, 2012.

[128] S. Yoshida, N. Wada, D. Hasegawa et al., "Semaphorin 3A induces odontoblastic phenotype in dental pulp stem cells," Journal of Dental Research, vol. 95, no. 11, pp. 1282-1290, 2016.

[129] S. G. Kim, Y. Zheng, J. Zhou et al., "Dentin and dental pulp regeneration by the patient's endogenous cells," Endodontic Topics, vol. 28, no. 1, pp. 106-117, 2013.

[130] K. M. Fawzy El-Sayed, P. Klingebiel, and C. E. Dorfer, "Tolllike receptor expression profile of human dental pulp stem/progenitor cells," Journal of Endodontics, vol. 42, no. 3, pp. 413-417, 2016.
[131] K. M. Fawzy El-Sayed, K. Jakusz, A. Jochens, C. Dorfer, and F. Schwendicke, "Stem cell transplantation for pulpal regeneration: a systematic review," Tissue Engineering Part B: Reviews, vol. 21, no. 5, pp. 451-460, 2015.

[132] K. M. Fawzy El-Sayed, G. M. Ahmed, E. A. Abouauf, and F. Schwendicke, "Stem/progenitor cell-mediated pulpal tissue regeneration: a systematic review and meta-analysis," International Endodontic Journal, vol. 52, no. 11, pp. 1573-1585, 2019.

[133] K. M. Fawzy El-Sayed, R. Elsalawy, N. Ibrahim et al., "The dental pulp stem/progenitor cells-mediated inflammatoryregenerative axis," Tissue Engineering Part B: Reviews, vol. 25, no. 5, pp. 445-460, 2019.

[134] Y. Zheng, X. Y. Wang, Y. M. Wang et al., "Dentin regeneration using deciduous pulp stem/progenitor cells," Journal of Dental Research, vol. 91, no. 7, pp. 676-682, 2012.

[135] M. Nakashima, K. Iohara, M. Murakami et al., "Pulp regeneration by transplantation of dental pulp stem cells in pulpitis: a pilot clinical study," Stem Cell Research \& Therapy, vol. 8, no. 1, p. $61,2017$.

[136] K. Xuan, B. Li, H. Guo et al., "Deciduous autologous tooth stem cells regenerate dental pulp after implantation into injured teeth," Science Translational Medicine, vol. 10, no. 455, article eaaf3227, 2018.

[137] G. Meza, D. Urrejola, N. Saint Jean et al., "Personalized cell therapy for pulpitis using autologous dental pulp stem cells and leukocyte platelet-rich fibrin: a case report," Journal of Endodontics, vol. 45, no. 2, pp. 144-149, 2019.

[138] S. Eramo, A. Natali, R. Pinna, and E. Milia, "Dental pulp regeneration via cell homing," International Endodontic Journal, vol. 51, no. 4, pp. 405-419, 2018.

[139] K. Iohara, L. Zheng, M. Ito et al., "Regeneration of dental pulp after pulpotomy by transplantation of $\mathrm{CD} 31^{-} / \mathrm{CD} 146^{-}$side population cells from a canine tooth," Regenerative Medicine, vol. 4, no. 3, pp. 377-385, 2009.

[140] K. Iohara, K. Imabayashi, R. Ishizaka et al., "Complete pulp regeneration after pulpectomy by transplantation of CD $105^{+}$stem cells with stromal cell-derived factor-1," Tissue Engineering Part A, vol. 17, no. 15-16, pp. 1911-1920, 2011.

[141] E. A. El Ashiry, N. M. Alamoudi, M. K. El Ashiry, H. A. Bastawy, D. A. El Derwi, and H. M. Atta, "Tissue engineering of necrotic dental pulp of immature teeth with apical periodontitis in dogs: radiographic and histological evaluation," Journal of Clinical Pediatric Dentistry, vol. 42, no. 5, pp. 373-382, 2018.

[142] D. M. Dohan Ehrenfest, M. Del Corso, A. Diss, J. Mouhyi, and J. B. Charrier, "Three-dimensional architecture and cell composition of a Choukroun's platelet-rich fibrin clot and membrane," Journal of Periodontology, vol. 81, no. 4, pp. 546-555, 2010.

[143] Y. J. Chen, Y. H. Zhao, Y. J. Zhao et al., "Potential dental pulp revascularization and odonto-/osteogenic capacity of a novel transplant combined with dental pulp stem cells and plateletrich fibrin," Cell and Tissue Research, vol. 361, no. 2, pp. 439455, 2015.

[144] F. Wang, Y. Jiang, X. Huang et al., "Pro-inflammatory cytokine TNF- $\alpha$ attenuates BMP9-induced osteo/odontoblastic differentiation of the stem cells of dental apical papilla (SCAPs)," Cellular Physiology and Biochemistry, vol. 41, no. 5, pp. 1725-1735, 2017. 
[145] K. Paryani and S. G. Kim, "Regenerative endodontic treatment of permanent teeth after completion of root development: a report of 2 cases," Journal of Endodontics, vol. 39, no. 7, pp. 929-934, 2013.

[146] P. R. Arany, A. Cho, T. D. Hunt et al., "Photoactivation of endogenous latent transforming growth factor- $\beta 1$ directs dental stem cell differentiation for regeneration," Science Translational Medicine, vol. 6, no. 238, article 238ra69, 2014.

[147] M. Li, X. Sun, L. Ma et al., "SDF-1/CXCR4 axis induces human dental pulp stem cell migration through FAK/PI3K/Akt and GSK3 $\beta / \beta$-catenin pathways," Scientific Reports, vol. 7, no. 1, article 40161, 2017.

[148] K. Iohara, M. Murakami, N. Takeuchi et al., "A novel combinatorial therapy with pulp stem cells and granulocyte colonystimulating factor for total pulp regeneration," Stem Cells Translational Medicine, vol. 2, no. 10, p. 818, 2013.

[149] K. Iohara, M. Fujita, Y. Ariji et al., "Assessment of pulp regeneration induced by stem cell therapy by magnetic resonance imaging," Journal of Endodontics, vol. 42, no. 3, pp. 397401, 2016.

[150] N. Ruangsawasdi, M. Zehnder, R. Patcas et al., "Effects of stem cell factor on cell homing during functional pulp regeneration in human immature teeth," Tissue Engineering Part A, vol. 23, no. 3-4, pp. 115-123, 2017. 